\title{
Тектоносфера
}

doi: https://doi.org/10.15407/gpimo2019.01.115

\section{С.М. Єсипович}

ДУ «Науковий центр аерокосмічних досліджень Землі Інституту геологічних наук НАН України», Київ

\section{АНТАРКТИДА - ПІВДЕННА ГЕОГРАФІЧНА ОБЛАСТЬ ЗЕМЛІ ЯК ГЕОДИНАМІЧНИЙ ЦЕНТР ФОРМУВАННЯ ПЕРВИННОї ПРОТОКОРИ ПЛАНЕТИ*}

Показано, що континент Антарктида, де розмішується Південний географічний полюс Землі, є геодинамічним центром формування первинної протокори планети. Саме в південну область планети був направлений викид тяжккоі мантійної речовини, яка і сформувала блоки-призми підвищеної жорсткості (БПЖ). Зараз вони розміщені в межах океанічних улоговин, окраїнних та внутрішніх морів, серединних масивів континентів.

Ключові слова: Антарктида, геодинамічний центр, океанічна земна кора, океани, континенти, блоки-призми підвищеної жорсткості.

\section{Вступ}

У XIX ст. Ч. Лайєль та Е. Реклю у своїх роботах описали основні географічні гомології поверхні планети. Практично всі відомі вчені XIX та XX ст., розвиваючи геологію, вивчали географічні гомології як на глобальному планетарному, так і локальному рівнях, вважаючи, що пояснення їх наблизить науку до розуміння того, як саме формувалася наша планета. У міру накопичення даних про будову інших космічних тіл Сонячної системи і, перш за все, Місяця, почали робити досить успішні зіставлення структурних рисунків їхньої поверхні з земними. З'явились припущення, що історія розвитку будь-якого космічного тіла закодована в будові його поверхні.

\section{Пояснення географічних гомологій}

Континент Антарктида розміщений дещо асиметрично відносно Південного географічного полюса нашої планети - зміщений від нього в континентальну ії частину. Нахил осі магнітного поля до

\footnotetext{
* Статтю надруковано як дискусійну.

(с) С.М. ЄСИПОВИЧ, 2019
} 
осі обертання складає $11^{\circ}$, однак в центрі планети вони не перетинаються, а магнітна вісь наближена до океанічної (тихоокеанської) частини планети.

Виділяють Східну та Західну Антарктиду згідно з їх розміщенням щодо Грінвіцького меридіана [10].

Східна Антарктида представлена кристалічним масивом докембрійського віку, складеним зім'ятими в складки та метаморфізованими осадовими породами, як і відповідні формації Північноамериканського, Африканського, Бразильського та Австралійського щитів. На цьому масиві лежать субгоризонтальні відклади від ранньопалеозойського до пермо-тріасового віку, тобто він залишався в стабільному жорсткому стані протягом останніх 600 млн рр. [10].

Західна Антарктида, навпаки, являє собою зону геосинклінального характеру, в якій накопичувались відклади, починаючи із силуру до міоцену впродовж ряду орогенічних циклів. За даними роботи [10], ця система подібна до системи Андів, а також острівні дуги, які відділяють Австралію від Тихого океану. Якщо виходити з геологічної циклічності, то під відкладами силуру можуть бути нашарування і більш ранніх геологічних епох - ордовику, кембрію та венду - до віку 740 млн рр.

Отже, Антарктида складається з двох суміжних тектонічних елементів, геологічна еволюція яких була різною: стабільна на сході та нестабільна на заході. Таке розміщення в загальних рисах подібне до Південної Америки, Австралії та Океанії - по суті молоді складчасті споруди цих структурних елементів, проходячи через Західну Антарктиду, формують південну частину геотектонічно активного Тихоокеанського кільця.

Фактичні дані про льодовикові періоди, наведені в роботі [10], свідчать, що області полярних шапок зміщені від океанічної (тихоокеанської) частини планети в бік континентальної її частини. Складається враження, що Тихий океан своїм гарячим поясом відштовхує від себе області льодового покриву. Зафіксовані обледеніння в ордовику, пермокарбоні та четвертинному періоді тяжіють до епох стиснення галактичних циклів [2], коли шляхи виходу на поверхню планети енергії зовнішнього ядра ускладнюються. Встановлено [10], що впродовж всього неогену, починаючи від його початку до четвертинного періоду, клімат Антарктики та Арктики був помірним. І хоча епоха стиснення Альпійського циклу першого порядку почалася 23,3 млн рр. тому, до часової позначки 6,7 млн рр. стадії стиснення перемежовувалися зі стадіями розширення [3], і тільки після цієї позначки почалося абсолютне стиснення зовнішньої оболонки планети, яке й призвело до появи льодових покривів у четвертинному періоді.

На рисунках 1, 2 та 3, взятих з роботи [4], показано розташування на поверхні планети блоків-призм підвищеної жорсткості (БПЖ). Вони виділені в межах глибоководних улоговин, окраїнних та внутрішніх морів, серединних масивів континентів. Антарктида - єдиний континент планети, який повністю оточений кільцем глибоководних улоговин, розірваних по суті лише в межах Антарктичного півострова, хребта Кергелен та о-вів Баллені. Саме в цих місцях починаються структурні зони, які, продовжуючись на північ, формують основні риси континентів у вигляді трьох ліній древніх кристалічних щитів: Антарктичний півострів - щити Південної та Північної Америк; хребет Кергелен - о-ви Крозе, плато Агульяс, щити Африки та Європи; о-ви Баллені - Антарктичне підняття, щити Австралії та Азії. 


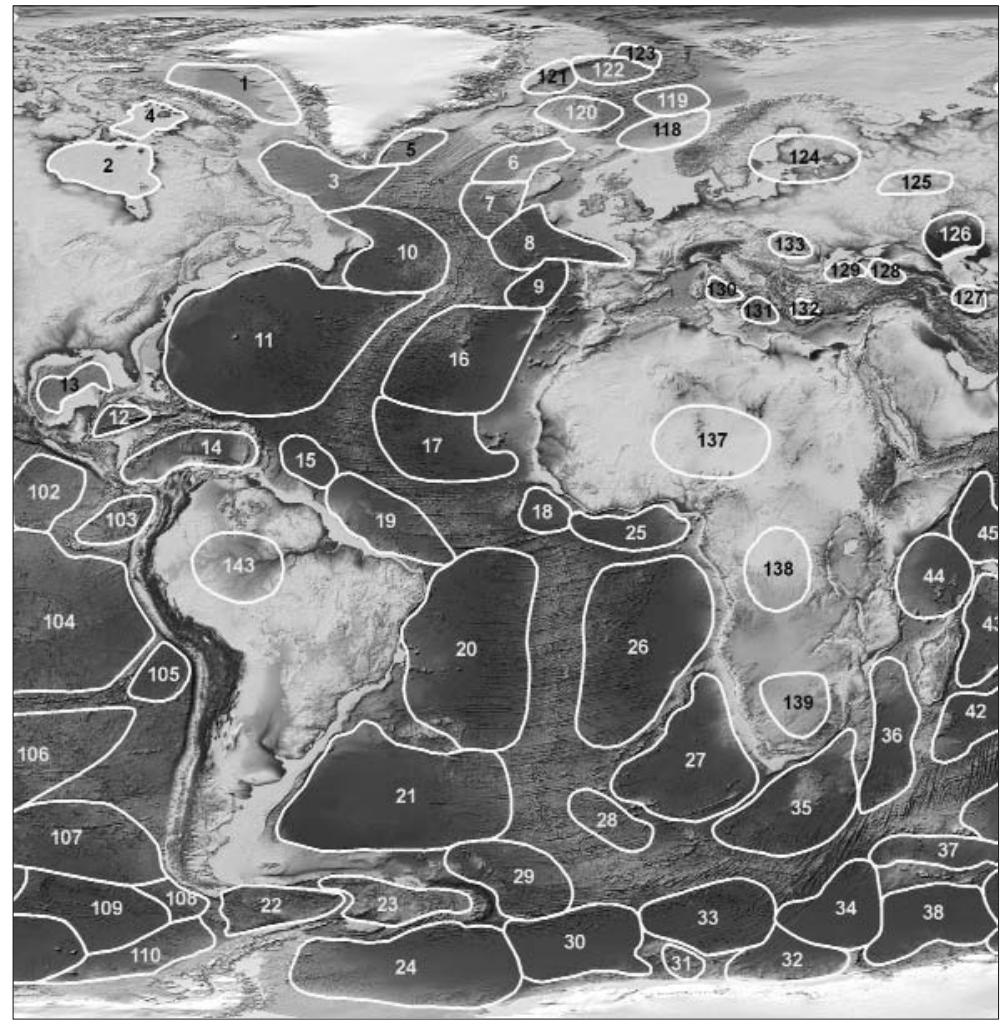

Puc. 1. Атлантичний океан. Тут і на рис. 2 і 3 цифрами позначені блоки-призми підвищеної жорсткості

Ще в XIX ст. Е. Реклю [8] встановив основні географічні гомології:

- переважну «континентальність» Північної півкулі та «океанічність» Південної, що відмічалось ще Ч. Лайєлем [5];

- трикутність форм всіх материків, які звужуються на південь, та протилежна трикутність форм океанів, що звужуються на північ;

• кільце суші навколо Північного Льодовитого океану та кільце океану навколо континенту Антарктида.

В цій роботі ми розглядаємо тільки континентальну частину планети і намагаємось пояснити географічні гомології Е. Реклю. Для океанічної частини планети приймаємо модель, в загальних рисах означену в роботі [4] - область Тихоокеанського кільця зазнає постійного впливу певної пресингуючої сили, яка діє з-за меж нашої Галактики, переміщуючи Сонячну систему, а можливо, і всю Галактику, в бік сузір'я Геркулеса. Очевидно, саме ця сила не дозволяє формуватись континентальним блокам земної кори в тихоокеанській частині планети. А формуються вони в континентальній частині по трьох вищезазначених зонах, причому дуже обережно, поступово розширюючи свої трикутні форми на північ 3 широти приблизно $40^{\circ}$.

Для подальших роздумів необхідно навести думки двох класиків української геології, відображені в роботах [1, 9]. В.Г. Бондарчук (1949) наголошував, що велетенська протяжність симатичної поверхні океанічного дна дозволяє розглядати симу як первинну, або космічну поверхню планети. 


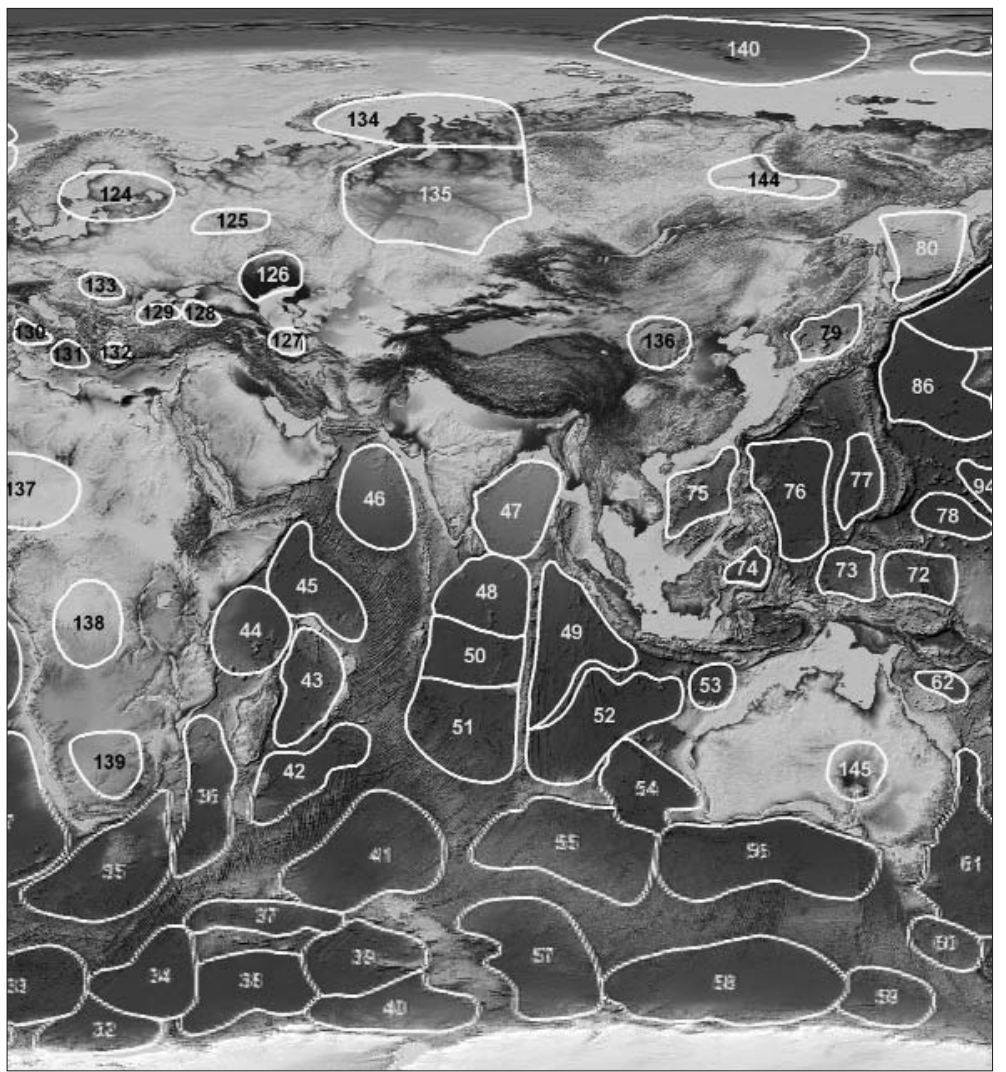

Puc. 2. Індійський океан

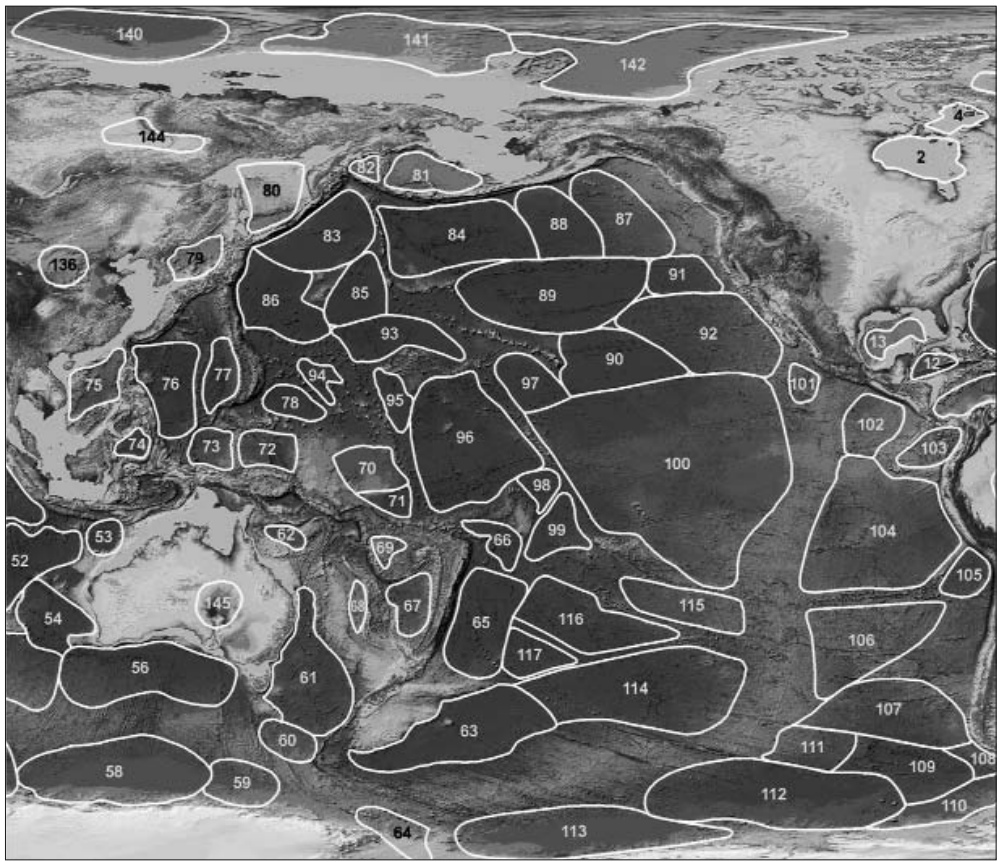

Puc. 3. Тихий океан 
Сіаль є похідним від сими, геологічно більш пізнім утворенням та вторинним геологічним рельєфом Землі. О.І. Слензак (1960), досліджуючи чарнокіти Придністров'я, показав, що гранітизація є самостійним фізико-хімічним процесом перетворення космічної земної кори (сими) в гранітоїдні породи (сіаль). Отже, спочатку була сформована первинна протокора (космічна), а вже потім формувалася вторинна, континентальна, в певних фізико-хімічних умовах (перш за все, за підвищених термобаричних значень). Саме тому сейсмічною томографією [6] зафіксована «дзеркальність» западин та підняттів поверхні ядра з континентами та океанами. Також розломна тектоніка океанів та континентів різко відмінна [9, 10]. Це стосується типів порушень, їх конфігурації та протяжності. Розломні зони континентів практично не виділяються на океанічному дні, а океанічні розломи в межах континентів швидко затухають.

3 даних роботи [4] про те, що первинна протокора планети зосереджена в межах глибоководних улоговин у БПЖ, які особливо щільно покривають саме південну, океанічну частину планети, випливає, що місця для формування вторинної, континентальної кори, в щільній упаковці ансамблів БПЖ просто не було. А це означає, що геодинамічна активність планети Земля на стадії утворення первинної протокори [4] була зосереджена переважно в південній частині планети. Щільно упакований панцир первинної протокори безумовно був рухомим завдяки розвитку серед БПЖ різноманітних міжблокових зон у вигляді океанічних хребтів, острівних дуг, ланцюжків гайотів. Він дозволяв на етапах розширення планети жорстким блокам рухатися під силами ротаційної динаміки із закруткою проти годинникової стрілки у Північній півкулі та за годинниковою - у Південній, формуючи S-подібні структурні лінії поверхні планети (П. Фурмар'є вважав їх найдавнішими структурними формами), а також просідати, утворюючи улоговини океанів на етапах стиснення.

Оскільки панцир БПЖ Індійського океану доходив до $20^{\circ}$ пн. ш., то зрозуміло, чому термічний екватор планети, згідно з дослідженнями М. Шварцбаха [10], для всіх геотектонічних епох розміщувався на північ від географічного.

Напрямок викиду енергії у вигляді магнітного потоку узгоджується з напрямком обертання Землі і, завдяки силам інерції та за правилом буравчика, спрямований на Південний географічний полюс. Тут відмічається ефект підвищеної щільності енергії і саме тому створюються умови росту мінеральної речовини планети. Причому, основне зростання буде спостерігатись в напрямку до поверхні на кільцях осі обертання [7]. Таким чином, континент Антарктида росте і сьогодні, маючи найвищий рівень стояння. Мілановський Є.Є. (1991) доводить, що в мезозойсько-кайнозойській історії планети почався процес загального розширення літосфери. При цьому в найпівденнішій частині Землі, поблизу Антарктиди, процес розходження блоків літосфери не компенсувався їх зближенням, а це могло бути лише при розширенні або всієї планети, або лише іiі Південного полюса, з розширенням на північ субширотних рифтових поясів [6].

\section{Висновки}

Область Південного полюса Землі може бути геодинамічним центром формування первинної протокори планети.

Необхідно допускати, що континент Антарктида, в результаті викиду на поверхню планети енергії зовнішнього ядра, геодинамічно активний і сьогодні. 
Так як континент Антарктида нерозривно поєднує в собі геологічні формації континентальної та океанічної частин планети, він є проявом нелінійної геодинаміки розвитку Землі.

\section{СПИСОК ЛІТЕРАТУРИ}

1. Бондарчук В.Г. Основы геоморфологии. Москва: Учпедгиз, 1949. 319 с.

2. Есипович С.М. История развития планеты Земля - пульсирующее расширение под действием космического прессинга. Одесса: Астропринт, 1998. 152 с.

3. Есипович С.М. Цикличность пульсирующего развития земной коры в ритмах расширения-сжатия для фанерозоя. Енергетика Землі, ії геолого-екологічні прояви, науково-практичне використання: Зб. наук. пр. К.: КНУТШ, 2006. С. 32-37.

4. Єсипович С.М., Савченко В.П., Бондаренко А.Д. та ін. Формування структури земної поверхні від протокори до геоструктур і морфоструктур морського дна. Геол. и полезн. ископ. Мирового океана. 2011. № 4. С. 47-63.

5. Лайель Ч. Основные начала геологии. Т. 1. Москва: Издание А.И. Глазунова, 1866.

6. Милановский Е.Е. Рифтогенез и его роль в тектоническом строении Земли и ее мезокайнозойской геодинамике. Геотектоника. 1991. №1. С. 3-21.

7. Орищенко И.В. Методология самоподобия геологических сред. Киев: Логос, 2004. 183 с.

8. Реклю Э. Земля, описание жизни земного шара. Вып. 1. Санкт-Петербург: О.Н. Попова, 1898.

9. Слензак О. И. Чарнокиты Приднестровья и некоторые общие вопросы петрологии. Киев: Изд-во АН УССР, 1960. $212 \mathrm{c.}$

10. Фурмарье П. Проблемы дрейфа континентов. Москва: Мир, 1971. 256 с.

Стаття поступила 10.09.2018

\section{C.M. Есипович}

\section{АНТАРКТИДА - ЮЖНАЯ ГЕОГРАФИЧЕСКАЯ ОБЛАСТЬ ЗЕМЛИ КАК ГЕОДИНАМИЧЕСКИЙ ЦЕНТР ФОРМИРОВАНИЯ ПЕРВИЧНОЙ ПРОТОКОРЫ ПЛАНЕТЫ}

Показано, что континент Антарктида, где находится Южный географический полюс Земли, является геодинамической центром формирования первичной протокоры планеты. Именно в южную область планеты, в соответствии с правилами буравчика относительно инерционных сил, был направлен выброс тяжелого мантийного вещества, который и формировал блокипризмы повышенной жесткости (БПЖ). Сейчас они размещены в пределах океанических впадин, окраинных и внутренних морей, срединных массивов континентов.

Ключевые слова: Антарктида, геодинамический центр, океаническая земная кора, океаны, континенты, блоки-призмы повышенной жесткости.

\section{S.M. Yesypovych}

ANTARCTICA IS THE SOUTHERN GEOGRAPHICAL AREA OF THE EARTH AS A GEODYNAMIC CENTER OF FORMATION OF THE PRIMARY CRUST OF THE PLANET

It is shown that the continent of Antarctica, where the South Geographical Pole of the Earth is located, is the geodynamic center of formation of the primary crust of the planet. It is in the southern region of the planet, in accordance with the rules of the driller with respect to inertial forces, that the heavy mantle substance emission was directed, which formed the blocks-prisms of increased rigidity. Now they are located within the limits of oceanic depressions, marginal and inland seas and middle massifs of continents.

Keywords: Antarctica, geodynamic center, oceanic crust, oceans, continents, prism blocks of increased dencity. 